\title{
Penerapan Teknologi Informasi dan Komunikasi Dalam Bidang Kehutanan Menuju Kehutanan 4.0
}

\author{
Dadang Jainal Mutaqin ${ }^{1}$, Muhamad Nafi Andriansyah ${ }^{2}$, Nur Hygiawati Rahayu ${ }^{3}$ \\ ${ }^{1}$ Fungsional Perencana Ahli Madya, Direktorat Kehutanan dan Konservasi Sumber \\ Daya Air, Bappenas \\ ${ }^{2}$ Tenaga Ahli di Direktorat Kehutanan dan Konservasi Sumber Daya Air, Bappenas \\ ${ }^{3}$ Direktur Kehutanan dan Konservasi Sumber Daya Air, Bappenas
}

Korespondensi: dj.mutaqin@bappenas.goid

\section{https://doi.org/10.47266/bwp.v4i2.99| halaman: $218-238$}

Dikirim: 22-06-2021 | Diterima: 01-09-2021 | Dipublikasikan: 20-09-2021

\begin{abstract}
Abstrak
Data yang diperoleh melalui teknologi informasi dan komunikasi (TIK) merupakan faktor penting dalam merumuskan kebijakan hal ini didasari oleh proses pengambilan kebijakan berbasis bukti (evidence-based policy) sangat bergantung pada ketersediaan data. Selain itu, perkembagan teknologi 4.0 yang saat ini dapat menjadi momentum yang tepat bagi sektor kehutanan untuk mengembangkan Kehutanan 4.0 yang dapat dirintis melalui penerapan TIK. Kajian ini mengidentifikasi kondisi penerapan TIK di bidang kehutanan saat ini dan kebutuhan yang diperlukan dalam rangka menuju Kehutanan 4.0 di masa mendatang. Hasil kajian menunjukan bahwa kondisi faktor pendukung penerapan TIK seperti infrastruktur, sumber daya manusia, standar/pedoman, alokasi anggaran, dan unit/tim khusus masih perlu ditingkatkan terutama pada institusi Kesatuan Pengelola Hutan (KPH). Kerja sama dengan pihak nonpengelola hutan yang berintegritas juga perlu dijalin untuk membantu meningkatkan penerapan TIK pada tingkat tapak. Sistem yang dibangun saat ini sudah menghubungkan walidata spasial dan unit kliring di lingkup KLHK. Namun demikian, sistem ini belum terhubung sampai tingkat tapak, terutama KPH karena belum ada regulasi yang mengatur integrasi data dari pusat, daerah, sampai tingkat tapak. Terkait dengan kebutuhan menuju Kehutanan 4.0, saat ini perlu diprioritaskan penyusunan kerangka regulasi dan peningkatan kualitas sumber daya manusia sebagai langkah awal menuju Kehutanan 4.0.
\end{abstract}

Kata kunci: pengelolaan hutan, teknologi informasi dan komunikasi, KPH, kehutanan 4.0 


\section{Penerapan Teknologi Informasi dan Komunikasi Dalam Bidang Kehutanan Menuju Kehutanan 4.0}

Dadang Jainal Mutaqin, Muhamad Nafi Andriansyah, dan Nur Hygiawati Rahayu

\section{Pendahuluan}

Hutan Indonesia memiliki luas yang signifikan yaitu separuh dari luas daratan Indonesia. Kementerian Lingkungan Hidup dan Kehutanan (2020) mencatat luas hutan Indonesia terus menerus berkurang setiap tahunnya karena adanya kebutuhan lahan untuk sektor lainnya. Ekspansi lahan budidaya terutama perkebunan kelapa sawit menjadi salah satu penyebab utama (driver) deforestasi di Indonesia (Curtis et al., 2018). Pada konteks ini, tata kelola hutan (forest governance) memiliki peran yang sentral dalam menentukan keberlanjutan jasa ekosistem hutan untuk mendukung kesejahteraan manusia dan pertumbuhan ekonomi yang berkelanjutan.

Tata kelola hutan di Indonesia masih menemui berbagai jenis permasalahan di tingkat pusat, daerah, sampai tingkat tapak. Ketidakpastian status kawasan hutan (Sinabutar et al., 2015), kapasitas unit manajemen yang masih kurang (Budiningsih et al., 2015) dan deforestasi (Austin et al., 2019) merupakan beberapa contoh permasalahan bidang kehutanan saat ini. Data dan teknologi informasi memegang peranan penting dalam mengatasi masalah-masalah tersebut karena proses penyusunan kebijakan berbasis bukti (evidence based policy) yang baik bergantung pada ketersediaan data yang diperoleh melalui penerapan teknologi informasi dan komunikasi (TIK). Menurut Reynolds et al. (2005), penerapan TIK dalam mendukung kebijakan berbasis bukti di bidang kehutanan merupakan hal yang penting karena TIK berperan dalam meningkatkan efisiensi dan efektivitas dari proses penyusunan kebijakan sekaligus juga menentukan alur dari proses penyusunan kebijakan itu sendiri. Dijelaskan lebih lanjut bahwa penerapan dan pengembangan TIK dalam bidang kehutanan didorong oleh beberapa faktor di antaranya: (1) meningkatkanya pemahaman pemahaman ilmiah tentang hutan; (2) tekanan publik terhadap pengambilan keputusan yang lebih baik; dan (3) kebutuhan institusi untuk terus meningkatkan daya saing

Castrén \& Pillai (2011) menjelaskan bahwa ketersediaan informasi yang baik memungkinkan terjadinya kolaborasi, transparansi, dan partisipasi dalam proses penyusunan kebijakan. Penyusunan kebijakan sudah seharusnya mengacu pada bukti ilmiah untuk memastikan kualitas dari kebijakan yang disusun. Namun demikian, proses penyusunan kebijakan pada kenyataannya masih merupakan proses negosiasi dan advokasi yang terjadi secara bersamaan antara banyak pemangku kepentingan pada berbagai topik yang dibahas. Pada kondisi ini, keputusan seringkali merupakan kompromi dari kepentingan yang saling berkompetisi, bukan berdasarkan data yang dapat dipertanggung jawabkan (Arnold et al., 2014).

Menurut Arnold et al. (2014), pada konteks kegiatan pengelolaan hutan, tingkat ketidakpastian dari hasil penerapan kebijakan seringkali cukup tinggi. Hal ini menyebabkan terciptanya berbagai perspektif terhadap alternatif kebijakan yang tersedia dan seringkali sulit untuk menemukan solusi yang dapat disepakati. Dijelaskan lebih lanjut, walaupun tujuan - tujuan mendasar seperti pengelolaan hutan berkelanjutan, konservasi kehati, dan 
pengentasan kemiskinan sudah menjadi tujuan bersama, namun konflik antar pemangku kepentingan dalam hal memutuskan cara terbaik untuk mencapai tujuan tersebut seringkali tidak dapat dihindari. Kondisi ini biasanya berjalan berlarut - larut dan berujung pada sebuah kebuntuan (deadlock) sampai akhirnya keadaan memaksa untuk dilakukan pengambilan keputusan dalam waktu singkat.

Selain itu, Arnold et al. (2014) juga menjelaskan bahwa pada kegiatan pengelolaan hutan terkadang data yang tersedia pada tingkat tapak dan daerah ketika diagregasi menunjukan perbedaan dengan data di tingkat pusat. Pada situasi seperti ini, penyusunan kebijakan yang tradisional, hirarkikal, dan top-down tidak dapat dipertahankan. Kebijakan kehutanan di tingkat nasional harus dapat merespon kebutuhan data di tingkat daerah bahkan sampai pada tingkat tapak. Kebutuhan data pada tingkat pusat, daerah, dan tapak seharusnya memiliki nilai kepentingan yang sama. Pada tingkat daerah dan tapak bahkan diperlukan data dengan tingkat presisi yang lebih tinggi dan variabel yang lebih detail.

Di Indonesia, pemanfaatan data dan teknologi informasi dan komunikasi di bidang kehutanan terutama yang berhubungan dengan data geospasial hingga saat ini masih terbatas pada pengambilan, pengolahan, dan penyajian data yang sifatnya statis. Sementara itu, tantangan-tantangan pada era industri 4.0 menuntut pengolahan data yang lebih dinamis. Teknologi 4.0 menawarkan interoperabilitas dan integrasi sebagaimana dijelaskan oleh Lu (2017). Penerapan TIK tidak hanya penting sebagai alat pendukung untuk penyusunan kebijakan saja, namun lebih jauh TIK memiliki nilai penting untuk mencapai Revolusi Industri Keempat (Industri 4.0) di bidang kehutanan. Meminjam prinsip yang sama dari sektor manufaktur sebagaimana dijelaskan oleh Alekseev et al. (2019), tahap pertama dari penerapan teknoligi 4.0 adalah persiapan sistem sosial - ekonomi yang termasuk didalamya tingkat digitalisasi (komputer dan internet) yang sudah melebihi $90 \%$.

Berkaitan dengan hal tersebut, informasi mengenai kondisi penerapan TIK dalam bidang kehutanan menjadi menjadi penting dalam meningkatkan kualitas pengambilan kebijakan di bidang kehutanan. Kajian ini disusun untuk memberikan gambaran mengenai penerapan TIK dalam konteks pengelolaan hutan di Indonesia yang saat ini dinilai masih belum diketahui secara pasti kondisinya. Selain itu, kajian ini juga disusun untuk mengidentifikasi kebutuhan dalam rangka menuju Kehutanan 4.0 di masa mendatang. Kajian diharapkan dapat memberikan rekomendasi bagi penyelenggaraan kebijakan berbasis bukti dalam sektor kehutanan di Indonesia.

\section{Metodologi}

Metode pengumpulan data yang digunakan pada kajian ini adalah melalui penyebaran kuesioner, focus group discussion (FGD), kunjungan lapangan dan studi literatur. Kuesioner "Penerapan Teknologi Informasi dan Komunikasi Menuju Kehutanan 4.0 di Indonesia" disusun untuk memperoleh penilaian dari instansi kehutanan tentang penerapan TIK di masing-masing institusi dalam melakukan kegiatan yang berhubungan dengan pengelolaan hutan. Studi literatur dilakukan untuk memperoleh gambaran mengenai penerapan TIK dan teknologi 4.0 dalam bidang kehutanan yang telah dilakukan di negara sebagai referensi untuk mengetahui faktor-faktor penting yang menentukan keberhasilan dari penerapan yang sudah pernah dilakukan. Sementara itu, FGD dilakukan untuk 
memperoleh informasi dari narasumber mengenai penerapan TIK yang saat ini sudah dilakukan di tingkat pusat. FGD juga menggali lebih lanjut mengenai pengembangan TIK yang sudah ada dan identifikasi kebutuhan sektor kehutanan menuju Kehutanan 4.0 berdasarkan analisis dari dari narasumber dan pakar yang berpartisipasi.

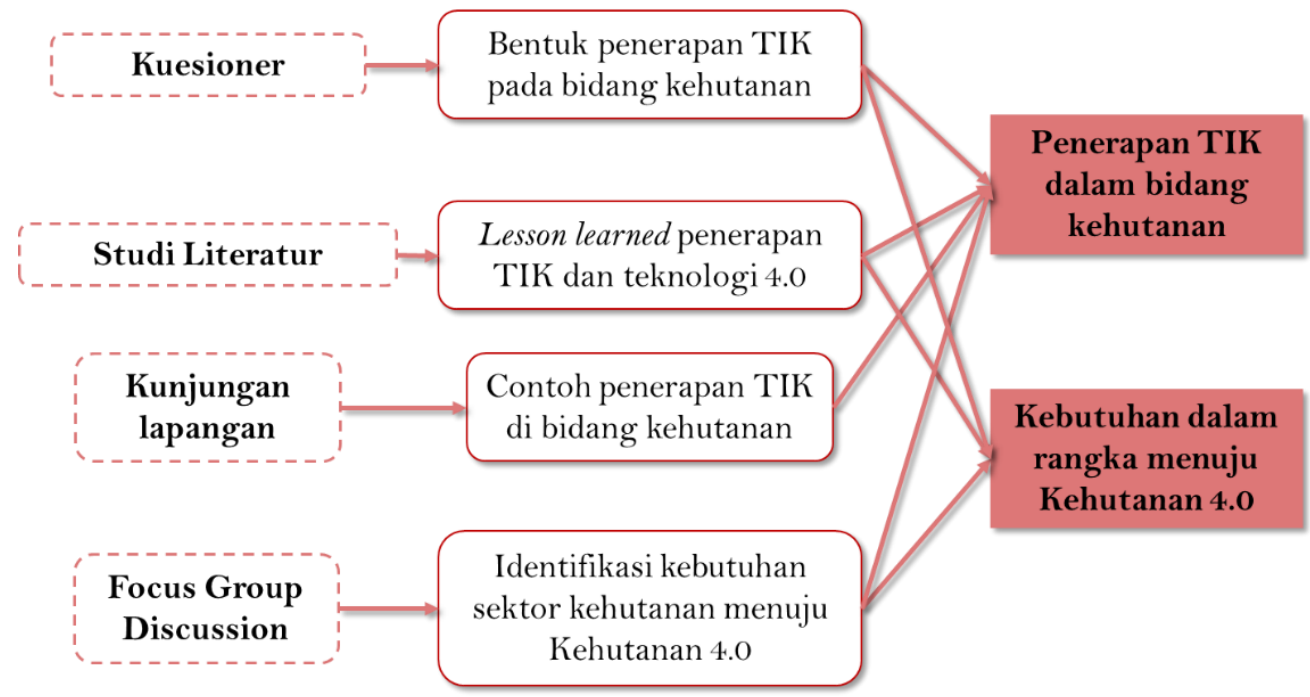

Gambar 1. Metodologi kajian

Kuesioner merupakan metode pengambilan data utama dalam kajian ini karena merupakan data primer dan bersifat lebih representatif dari stakeholders kehutanan yang ada, terutama KPH. Pada Gambar 2 diperlihatkan pertanyaan-pertanyaan dari kuesioner yang disusun, di antaranya menggambarkan: (1) penerapan TIK pada masing-masing institusi pengelola hutan; (2) persepsi nonpengelola hutan terhadap penerapan TIK di bidang kehutanan; (3) kontribusi nonpengelola hutan dalam penerapan TIK di bidang kehutanan. Variabel yang menjadi bahan pertanyaan disusun berdasarkan studi yang berkaitan dengan penerapan TIK dalam konteks e-government (Ziemba et al., 2016), studi yang berkaitan secara langsung dengan penerapan TIK di bidang kehutanan (Castrén \& Pillai, 2011), maupun analisis awal dari tim penulis. Adapun responden kuesioner pada kajian ini dibagi menjadi dua kelompok. Kelompok dibedakan berdasarkan perannya dalam kegiatan pengelolaan hutan. Kelompok pertama merupakan pengelola hutan yang memiliki kewenangan melakukan kegiatan di kawasan hutan. Kelompok ini terdiri dari unit kerja KLHK di tingkat pusat, unit pelaksana teknis KLHK, pemerintah daerah sektor kehutanan, Kesatuan Pengelolaan Hutan, dan pemegang izin konsesi (BUMN dan BUMS). Kelompok kedua adalah kelompok nonpengelola hutan yang tidak melakukan kegiatan pengelolaan hutan secara langsung namun dapat membantu pemerintah atau pengelola hutan lainnya dalam mengelola hutan. Instansi yang termasuk nonpengelola hutan adalah mitra pembangunan, akademisi, dan Kementerian/Lembaga (K/L) lainnya. 


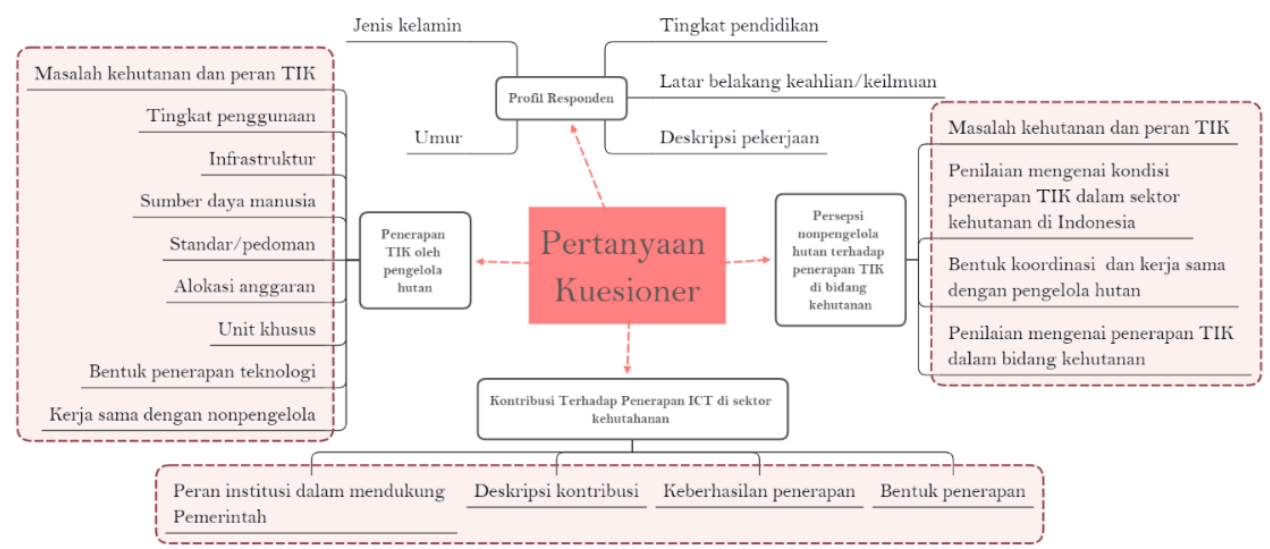

Gambar 2. Pertanyaan kuesioner

\section{Analisis}

\subsection{Masalah di Bidang Kehutanan dan Peran TIK Dalam Menyelesaikannya}

Berdasarkan hasil pengolahan kuesioner diketahui bahwa secara umum masalah di bidang kehutanan yang perlu diselesaikan saat ini berkaitan dengan kepastian batas kawasan hutan dan ketersediaan data untuk pengambilan keputusan. Ketidakpastian batas kawasan hutan dipengaruhi oleh keterbukaan data dan informasi yang seringkali didominasi oleh hanya salah satu pihak (Sinabutar et al., 2015). Selain itu ketidakpastian status kawasan juga dipengaruhi oleh isu sosial - budaya di sekitar kawasan hutan. Penerapan TIK berperan penting dalam menyelesaikan masalah yang ada di bidang kehutanan saat ini. Hal ini terlihat dari mayoritas penilaian responden bahwa TIK berpengaruh $80 \%$ dalam menyelesaikan masalah-masalah di bidang kehutanan. Penerapan TIK pada berbagai kegiatan pengelolaan hutan dinilai dapat meningkatkan efektifitas dan efisiensi dalam melakukan perencanaan dan implementasi program. Selain itu, penerapan TIK juga dapat meningkatkan akurasi data dan terciptanya transparansi publik (Gambar 3)

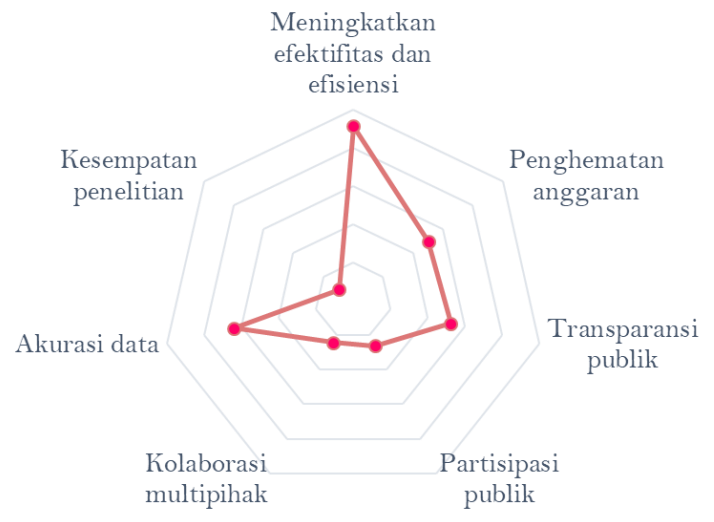

Gambar 3. Persepsi responden terhadap peran TIK dalam menyelesaikan masalah di bidang kehutanan 
Sementara itu, keuntungan dari penerapan TIK yang belum banyak dimanfaatkan adalah lahirnya kesempatan-kesempatan penelitian baru. Kesempatan penelitian baru akan menghasilkan akumulasi inovasi yang bermuara pada revolusi industri. Hal ini merupakan salah satu syarat untuk Revolusi Industri Keempat di sektor kehutanan (industri 4.0). Bidang kehutanan dinilai belum mengarah ke Industri 4.0 karena belum banyaknya akumulasi inovasi sebagai syarat dalam revolusi industri sebagaimana disebutkan oleh Alekseev et al., (2019). (Choudhry \& O'Kelly, 2018) bahkan menjelaskan lebih jauh bahwa transformasi digital dalam bidang kehutanan dimulai justru saat belum adanya teknologi yang mumpuni untuk diterapkan. Transformasi bermula dari adanya kebutuhan untuk menyelesaikan permasalahan yang saat ini dihadapi. Dalam konteks ini, penelitian-penelitian baru menjadi penting dalam memberikan solusi terhadap masalah yang saat ini dihadapi.

\subsection{Tingkat Penerapan TIK di Bidang Kehutanan}

Penerapan TIK dalam bidang kehutanan saat ini masih belum maksimal dan masih perlu ditingkatkan. Dari segi tingkat penerapan TIK, teramati adanya perbedaan persepektif antara pengelola hutan dan nonpengelola hutan. Pengelola hutan cenderung menilai bahwa tingkat penerapan TIK di bidang kehutanan saat ini adalah pada tingkat Sedang-Tinggi sementara nonpengelola hutan menilai bahwa tingkat penerapan TIK dalam bidang kehutanan masih cenderung pada tingkat Rendah-Sedang. Gambar 4 memperlihatkan perbandingan antara tingkat penerapan TIK pada bidang kehutanan dari perspektif pengelola dan nonpengelola, walaupun dengan jumlah total yang cukup berbeda antara pengelola dan nonpengelola hutan. Berdasarkan kecenderungan ini dapat terlihat bahwa tingkat penerapan TIK dalam bidang kehutanan di Indonesia masih pada tingkat Sedang. Kecenderungan peningkatan dimungkinkan terjadi dengan mempertimbangkan kondisi faktor pendukung yang ada saat ini dan intervensi kebijakan yang dilakukan.

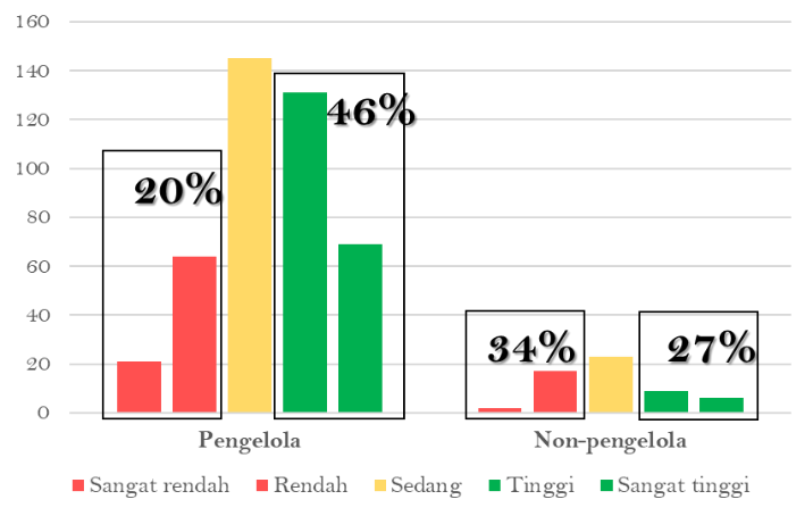

Gambar 4. Tingkat penerapan TIK dalam bidang kehutanan

\subsection{Kondisi Faktor Pendukung Penerapan TIK di Bidang Kehutanan}

Kondisi faktor pendukung penerapan TIK di bidang kehutanan dapat diamati pada Tabel 1 berdasarkan kelompok institusi yang mengisi kuesioner. Dari berbagai institusi kehutanan, KPH merupakan institusi yang masih memerlukan peningkatan dari segi infrastruktur, sumber daya manusia, standar/pedoman, anggaran, dan unit khusus yang 
menangani TIK. Sementara itu, penerapan TIK pada UPT KLHK dan pemegang izin konsesi sudah lebih baik dan perlu untuk terus ditingkatkan.

Tabel 1. Kondisi Faktor Pendukung Penerapan TIK di Bidang Kehutanan

\begin{tabular}{clccc} 
No. & \multicolumn{1}{c}{ Variabel } & KPH & UPT KLHK & Pemegang izin konsesi \\
\hline 1 & Infrastruktur & Rendah - Sedang & Sedang - Tinggi & Sedang - Tinggi \\
2 & Sumber daya manusia & Rendah - Sedang & Sedang - Tinggi & Sedang - Tinggi \\
3 & Ketersediaan anggaran & $41 \%$ & $71 \%$ & $83 \%$ \\
4 & Ketersediaan standar/pedoman & $25 \%$ & $84 \%$ & $64 \%$ \\
5 & Unit/tim khusus & $16 \%$ & $69 \%$ & $81 \%$ \\
\hline
\end{tabular}

Sumber: Hasil pengolahan kuesioner

\section{a. Infrastruktur}

Dari total $195 \mathrm{KPH}$ yang melaporkan kondisi infrastruktur, terdapat 77 instansi KPH (39\%) yang melaporkan kondisi infrastruktur di bawah Cukup Memadai. Menurut Castrén dan Pillai (2011), infrastruktur dan internet merupakan elemen eksternal kunci dalam operasionalisasi TIK di bidang kehutanan selain elemen internal yang berfokus pada organisasi. Infrastruktur yang dimaksud termasuk di dalamnya jaringan listrik, jaringan telepon, jaringan transportasi menuju lokasi tapak, penetrasi internet, persentasi penggunaan ponsel pintar, dan akses terhadap penggunaan internet. Lokasi KPH yang cenderung pada wilayah yang sulit terjangkau dapat menjadi penyebab kurangnya beberapa infrastruktur pendukung penerapan TIK.

\section{b. Sumber Daya Manusia}

Terkait dengan aspek sumber daya manusia, dari total 195 KPH yang berpartisipasi, terdapat $72 \mathrm{KPH}(38 \%)$ yang melaporkan kondisi sumber daya manusia di bawah Memadai. Hal ini dapat menggambarkan kondisi sumber daya manusia dalam instansi kehutanan di Indonesia yang perlu untuk ditingkatkan baik dari segi kualitas maupun kuantitasnya karena sumber daya manusia merupakan aspek yang bersifat fundamental dalam penerapan TIK di bidang kehutanan. Berdasarkan hasil studinya dari beberapa kasus yang dipelajari, Castrén \& Pillai (2011) menjelaskan bahwa memahami konteks dan kapasitas lokal merupakan prakondisi yang penting untuk memperkenalkan sudut pandang baru dalam mengelola hutan yaitu dengan penerapan TIK. Hal ini akan membuka kesempatan baru yang lebih besar terhadap perubahan cara mengelola hutan yang lebih baik di kemudian hari. Walaupun hal ini akan memakan waktu, namun pada gilirannya akan tercipta pondasi yang kuat untuk penerapan TIK yang lebih luas ke depannya.

\section{c. Alokasi Anggaran}

Dalam hal alokasi anggaran, masih terdapat 59\% dari institusi KPH melaporkan belum adanya anggaran untuk penerapan TIK dalam pengelolaan hutan, sementara UPT KLHK dan pemegang izin konsesi cenderung sudah memiliki alokasi anggaran untuk penerapan TIK. Berdasarkan analisis lebih jauh diketahui bahwa alokasi anggaran diperuntukkan untuk beberapa hal seperti diperlihatkan pada Gambar 5. Mayoritas dari responden melaporkan bahwa anggaran diperuntukkan untuk pengadaan GPS dan alat-alat pemetaan kemudian untuk pengadaan komputer GIS dan pengembangan dan perawatan sistem dan database yang dibangun. Hal ini dapat menjadi informasi awal bahwa GPS merupakan perangkat yang sangat penting dalam kegiatan pengelolaan hutan, begitu juga dengan perangkat pengolahan datanya seperti komputer berkapasitas khusus untuk 
pengolahan data spasial. Selain itu, anggaran juga dialokokasikan untuk pengadaan drone yang saat ini menggantikan peran citra satelit karena dinilai lebih akurat dan datanya bersifat real time.

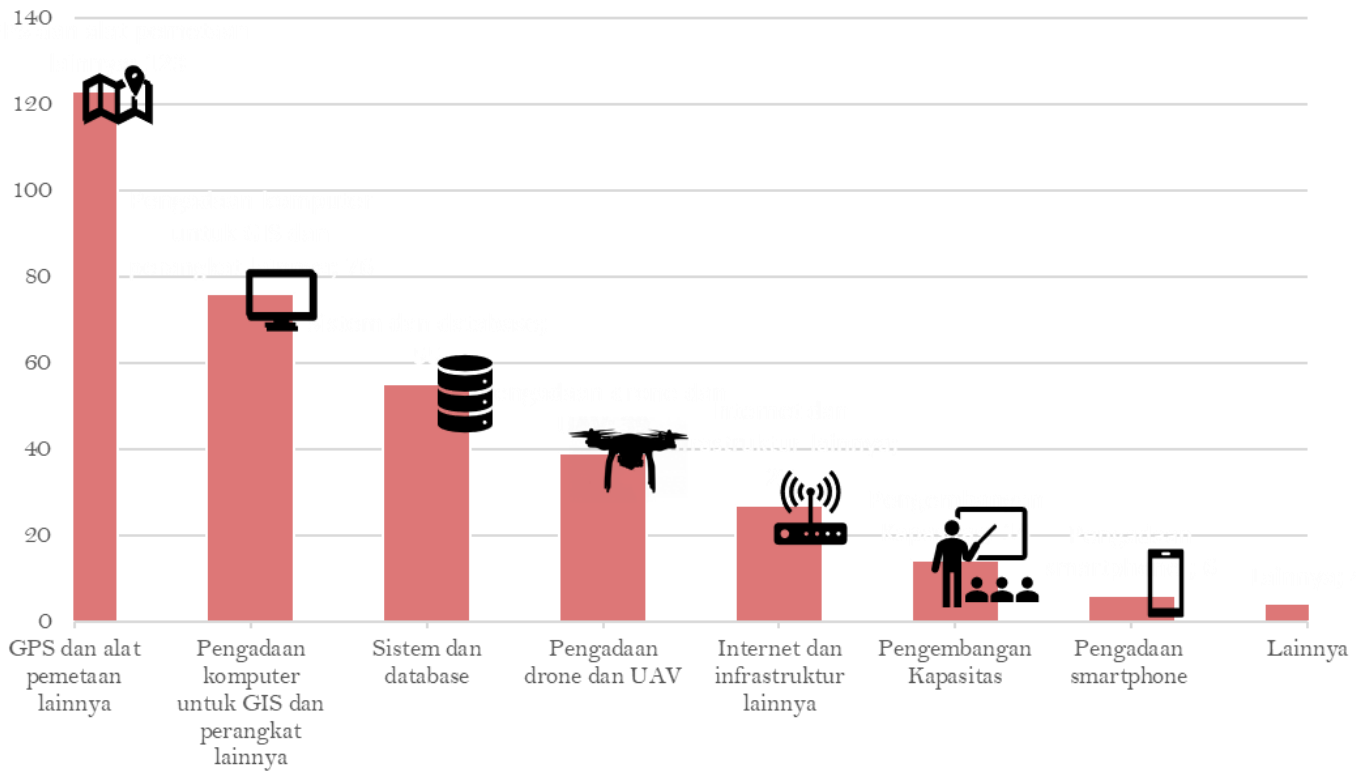

Gambar 5 Ragam peruntukan alokasi anggaran penerapan TIK di bidang kehutanan

\section{d. Standar/Pedoman}

Secara umum, ketersediaan standar/pedoman yang diacu dalam kegiatan pengelolaan hutan berbasis TIK masih kurang lengkap terutama di institusi KPH. Terdapat 194 institusi melaporkan sudah memiliki standar dalam menerapkan TIK pada kegiatan pengelolaan hutan. Sementara itu, masih ada 201 institusi yang belum memiliki standar dalam menerapkan TIK dalam kegiatan pengelolaan hutan. Beberapa standar sudah secara spesifik mengatur teknis pelaksanaan pengelolaan hutan berbasis TIK sementara beberapa standar masih bersifat umum. Beberapa contoh standar resmi yang dilaporkan dalam pengisian kuesioner di antaranya:

- Peraturan Menteri LHK Nomor P.28/MenLHK/Setjen/KUM.1/2/2016 tentang Jaringan Informasi Geospasial Lingkup KLHK

- Peraturan Menteri Kehutanan Nomor P.67/Menhut-II/2006 tentang Kriteria dan Standar Inventarisasi Hutan.

- Peraturan Menteri Lingkungan Hidup dan Kehutanan Republik Indonesia Nomor P.51/Menlhk/Setjen/Kum.1/9/2019 tentang Perubahan Kedua atas Peraturan Menteri Kehutanan Nomor P.56/Menhut-II/2008 tentang Tata Cara Penentuan Luas Areal Terganggu dan Areal Reklamasi dan Revegetasi untuk Perhitungan Penerimaan Negara Bukan Pajak Penggunaan Kawasan Hutan. 
- Pasal 13 Peraturan Menteri Lingkungan Hidup dan Kehutanan Nomor: P.73/Menlhk/Setjen/Kum.1/12/2017 Tentang Pedoman Penyelenggaraan dan Pelaporan Inventarisasi GRK.

- Peraturan Dirjen PKTL Nomor: P.4/PKTL/SETDIT/KUM.1/3/2020 tentang Pedoman Penyelenggaraan dan Penyebarluasan Informasi Geospasial Lingkup Kementerian Lingkungan Hidup dan Kehutanan,

- Perdirjen Planologi Kehutanan Nomor P1/VII-IPSDH/2015 tentang Pedoman Pemantauan Penutupan Lahan.

- Perdirjen Planologi Kehutanan Nomor P.3/VII-PSDH/2014 tentang Petunjuk Teknis Penggambaran dan Penyajian Peta Kehutanan

- Prosedur Kerja Sistem Manajemen Perhutani (PK-SMPHT) 01-004 tentang Inventarisasi Hutan.

- PK-SMPHT 01-006 tentang Penyusunan Rencana Pengaturan Kelestarian Hutan.

- PK-SMPHT 01.010 tentang Pengunaan GPS.

- PK-SMPHT 01-014 tentang Sistem Informasi Sumberdaya Hutan.

- PK-SMPHT 01-013 tentang SIG-Perpetaan Digital.

- PK SMPHT 16-006 tentang Implementasi Infrastruktur TI.

Terlepas dari daftar yang disebutkan di atas, masih terdapat standar/pedoman yang mungkin tidak terlaporkan dalam pengisian kuesioner. Selain itu, beberapa standar/pedoman dilaporkan tidak dalam bentuk formal namun dapat teridentifikasi fungsinya dalam penerapan TIK sebagaimana disebutkan berikut:

- Pedoman Pengaturan Atribut Data dan Informasi Geospasial Bagi Pengguna Eksternal KLHK.

- Petunjuk teknis Penafsiran Citra Satelit Resolusi Sedang Untuk Update Data Penutupan Lahan Nasional (Juknis 1/PSDH/PLA.1/7/2020).

- Pedoman Pembuatan Peta Tematik Kehutanan.

- Pedoman Penataan Batas Kawasan Hutan.

- Pedoman Pengecekan Lapangan Data Hasil Penafsiran Citra.

- Pedoman Teknis Penataan Batas dengan GPS Geodetik.

- Pedoman Inventarisasi Tegakan Sebelum Penebangan (ITSP).

- Pedoman Inventarisasi Hutan Menyeluruh Berkala.

- Pedoman Verifikasi Pembayaran Pendapatan Negara Bukan Pajak (PNBP) Penggunaan Kawasan Hutan.

- Pedoman Pengukuhan Kawasan Hutan berbasis GNSS.

- Pedoman Penerbitan Data dan Informasi Geospasial. 
- Pedoman Identifikasi Lahan Kritis dan Penentuan Lokasi ntuk Pelaksanaan Kegiatan Rehabilitasi Hutan.

- Pedoman Penyusunan Data Lahan Kritis dan Klasifikasi DAS.

- Pedoman Persemaian Pemeliharaan Tanaman Hutan.

- Pedoman Penataan Areal Kerja.

- Pedoman Pemutakhiran Data dan Informasi.

- Pedoman Pengamanan Batas Areal Kerja IPPKH dan SOP.

- Pedoman Kegiatan Inventarisasi dan Pemetaan Kerawanan Gangguan Keamanan Hutan.

- Pedoman Patroli Resort Base Management (RBM) berbasis SMART Patrol.

- Pedoman Pelaporan Banjir dan Tanah Longsor.

- Pedoman Pemungutan dan Pengumpulan HHBK Dan TPT HHBK.

- Pedoman Penjualan Online Toko Perhutani.

- Pedoman Pendakian Rinjani.

\section{e. Unit Manajemen}

Unit manajemen yang khusus menangani TIK dalam kegiatan pengelolaan hutan pada masing-masing institusi secara umum berfokus pada kegiatan yang berhubungan erat dengan data, data spasial, pengukuran, inventarisasi, dan kegiatan lainnya yang memanfaatkan perangkat TIK. Beberapa institusi menafsirkan jabatan struktural sebagai unit khusus yang menangani TIK dalam kegiatan pengelolaan hutan, namun hal tersebut dikelompokan sebagai kategori "belum memiliki unit khusus" karena jabatan struktural yang bersangkutan telah memiliki tugas dan fungsi teresendiri.

Melalui Tabel 1 terlihat bahwa ketersediaan unit manajemen di KPH menunjukan kecenderungan yang berbeda dengan UPT KLHK dan pemegang izin konsesi. Dari total $195 \mathrm{KPH}$ yang berpartisipasi, hanya $16 \%$ yang melaporkan ada unit khusus yang menangani TIK dalam kegiatan pengelolaan hutan, sedangkan sisanya melaporkan 'belum ada' atau tergolong sebagai jabatan struktural yang ditetapkan melalui peraturan Gubernur. Untuk struktur organisasi di KPH yang diatur melalui peraturan Gubernur, hasil kuesioner memperlihatkan bahwa unit manajemen yang banyak berhubungan dengan TIK dalam mengolah data dan informasi baik nonspasial maupun spasial adalah Seksi Perencanaan dan Pemanfaatan Hutan. Selain itu, KPH juga terdiri dari jabatan fungsional yang menangani bidang yang lebih fokus seperti pejabat fungsional umum yang membidangi data dan neraca sumber daya hutan, pejabat fungsional umum yang membidangi penataan kawasan hutan, dan pejabat fungsional umum yang membidangi pengukuran dan pemetaan hutan.

Hal sebaliknya dilaporkan oleh instansi UPT KLHK dan pemegang izin konsesi (Tabel 1). Mayoritas responden dari UPT KLHK dan pemegang izin melaporkan sudah ada unit khusus yang menangani penerapan TIK dalam kegiatan pengelolaan hutan. Sekitar 69\% dari UPT KLHK yang berpartisipasi dalam kuesioner ini menyatakan bahwa sudah memiliki unit khusus yang menangani penerapan TIK dalam bidang kehutanan, sedangkan untuk 
pemegang izin konsesi terdapat 79 (81\%) yang melaporkan sudah memiliki unit khusus. Perhitungan masih mempertimbangkan keberadaan individu yang memiliki tugas khusus sebagai 'unit' khusus yang menangani penerapan TIK dalam kegiatan pengelolaan hutan. Berdasarkan hasil pengisian kuesioner, dikenali bahwa unit khusus yang terkait dengan penerapan teknologi informasi dan komunikasi menangani hal yang berkaitan dengan pemetaan dan pengumpulan data berbasis digital. Beberapa contoh yang unit kerja yang disampaikan dalam pengisian kuesioner di antaranya:

- Tim Jaringan Informasi Geospasial

- Kelompok Kerja Data dan Informasi

- Tim Pengelola Situation Room

- Divisi IT

- Sub Seksi Kesisteman, Pengendalian Kinerja, dan Teknologi Informasi

- Tim Forest Management Information System

- Tim Forest Information Technology

- Tim khusus SIPPUH

- Tim pemetaan

- Operator GIS

\section{f. Jenis Teknologi}

Dalam hal teknologi yang diterapkan, penerapan TIK di bidang kehutanan saat ini masih berfokus pada penerapan teknologi 3.0 dan belum ditemukan penerapan teknologi 4.0 secara masif di hampir semua institusi kehutanan di Indonesia. Penerapan teknologi digital didominasi oleh penggunaan aplikasi GIS dan GPS (Global Positioning System) berbasis smartphone yang dinilai sangat mudah digunakan untuk keperluan lapangan dan relatif murah. Selain itu, software pengolahan data geospasial juga sudah marak digunakan untuk keperluan pengelolaan data spasial (Gambar 6). 


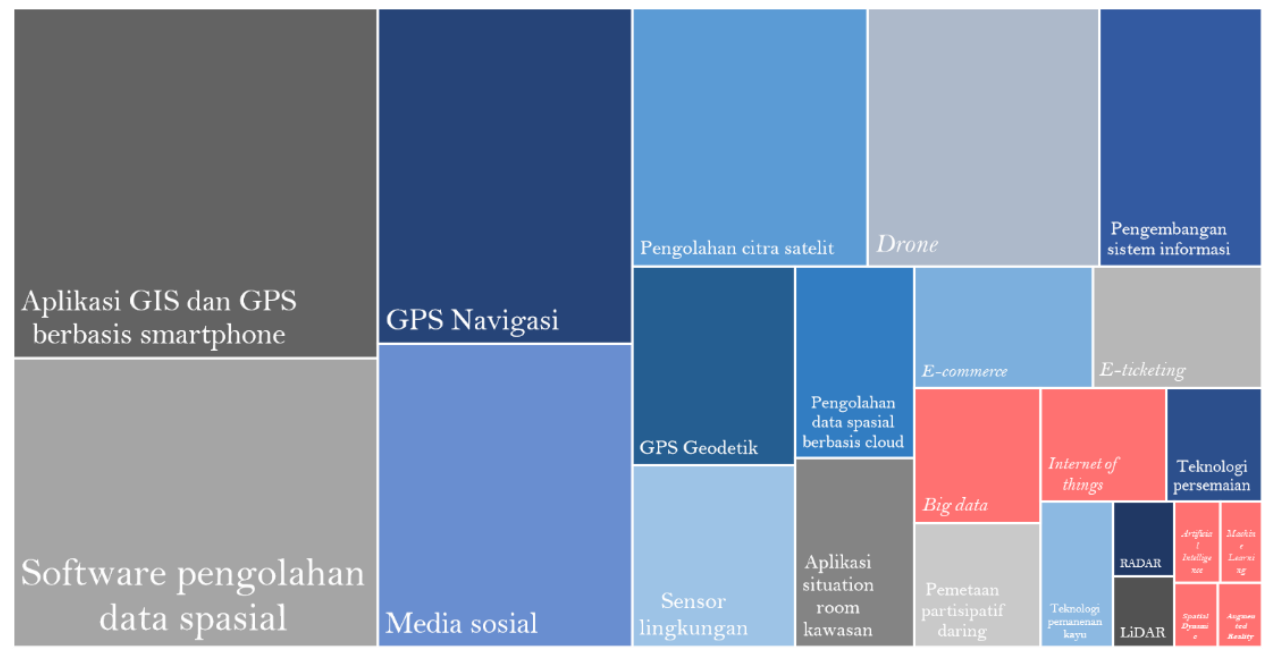

Gambar 6. Bentuk teknologi yang diterapkan

Menurut Castrén \& Pillai, (2011), pemilihan jenis teknologi yang diterapkan (misalkan penggunaan aplikasi open-source) sangat sensitif terhadap kapasitas lokal, anggaran, dan strategi penerapan TIK yang disusun pada masing-masing institusi. Pilihan mungkin saja mengacu pada ketersediaan anggaran yang ada. Meskipun demikian, institusi kehutanan juga harus sejak awal melakukan investasi terhadap teknologi yang lebih reliabel dan fleksibel penggunaannya walaupun dengan biaya yang lebih besar.

\subsection{Kerja Sama Antara Institusi Pengelola Hutan dan Nonpengelola Hutan}

Penerapan TIK di bidang kehutanan juga tidak terlepas dari peran nonpengelola hutan yang membantu proses pengelolaan hutan melalui penelitian, pendampingan, donor, fasilitasi, dan lain sebagainya. Secara umum, kerja sama antara pengelola hutan dan nonpengelola hutan masih perlu ditingkatkan. Berdasarkan hasil kuesioner teridentifikasi 93 institusi pengelola hutan di lapangan yang melaporkan sudah bekerja sama dengan mitra pembangunan (Gambar 7). Kerja sama yang dilakukan beragam jenisnya, di antaranya: peningkatan kapasitas sumber daya manusia di KPH, pendampingan dalam melakukan pengamanan hutan berbasis teknologi informasi, dan penelitian bersama di kawasan hutan $40 \mathrm{KPH}$ yang sudah bekerja sama dengan mitra pembangunan. Sementara itu, sebanyak 245 institusi $72 \%$ dari jumlah responden yang menjawab pertanyaan ini melaporkan bahwa belum ada kerja sama yang terjalin dengan pihak luar manapun. Untuk institusi KPH teridentifikasi 40 institusi KPH di lapangan yang melaporkan sudah bekerja sama dengan mitra pembangunan. Jumlah ini hanya sebesar $21 \%$ dari total KPH yang berpartisipasi dalam pertanyaan ini. 


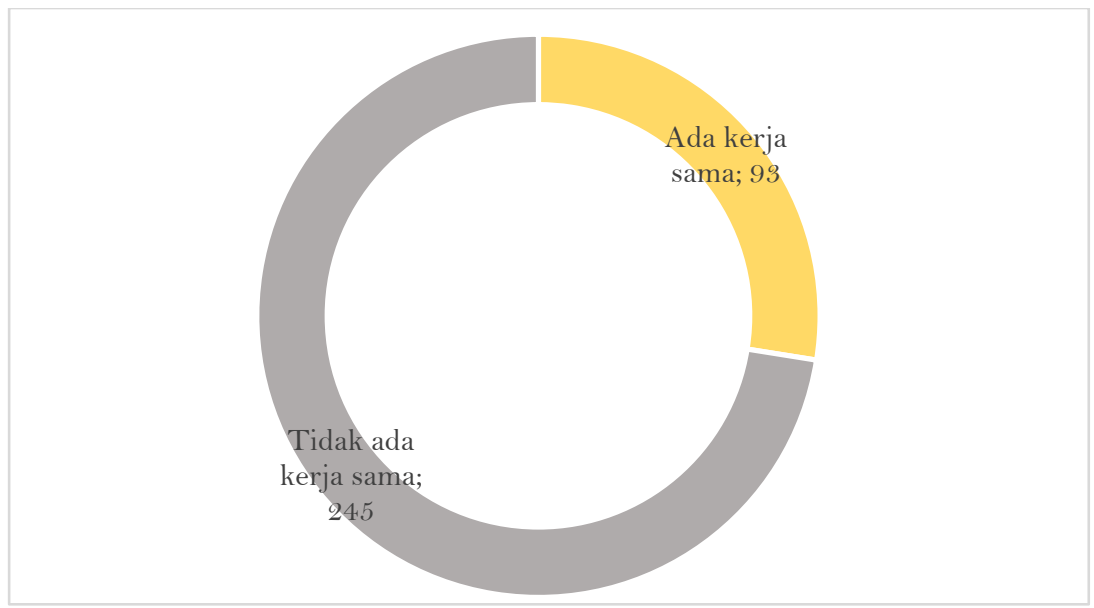

Gambar 7. Proporsi keberadaan kerja sama antara pihak pengelola hutan dan non pengelola hutan

Kerja sama yang masih minim sebaiknya dapat ditingkatkan karena pihak nonpengelola hutan dapat membantu kegiatan pengelolaan hutan yang dilaksanakan di tingkat tapak oleh KPH atau institusi level tapak lainnya. Peningkatan kualitas dan kuantitas faktor pendukung penerapan TIK dapat dibantu melalui kehadiran mitra pembangunan di lapangan. Mitra pembangunan yang berintegritas, berkomitmen, dan terpercaya juga dapat menjadi pendorong kualitas pengelolaan hutan secara umum di level tapak melalui penerapan inovasi-inovasi teknologi beserta dengan peningkatan sumber daya manusia yang ada di dalamnya. Kehadiran mitra pembangunan juga dapat meningkatkan transparansi kerja sektor pemerintah melalui kegiatan yang dilakukan bersama. Lebih jauh, kesempatan kolaborasi penelitian juga meningkat sehingga meningkatnya akumulasi teknologi sebagai prasyarat untuk revolusi industri lebih lanjut.

\subsection{Penyelenggaraan Informasi Geospasial di Bidang Kehutanan}

Saat ini penerapan TIK dalam bidang kehutanan terutama yang bersifat spasial di level nasional dipusatkan di Direktorat Inventarisasi dan Pemantauan Sumber Daya Hutan (IPSDH), Direktorat Jenderal Planologi Kehutanan dan Tata Lingkungan (PKTL), KLHK. Direktorat IPSDH juga merupakan unit kliring data spasial yang bertanggung jawab dalam penyimpanan, pengamanan, dan penyebarluaan informasi geospasial di KLHK. Direktorat IPSDH terdiri dari empat unit kerja yang berfokus pada: (1) inventarisasi sumber daya hutan terrestrial; (2) pemantauan sumber daya hutan melalui data penginderaan jauh; (3) pemetaan, analisis spasial, dan dokumentasi tematik; dan (4) jaringan data spasial kehutanan dalam hal berbagi pakai dan pertukaran data. Penyelenggaraan jaringan informasi geospasial (JIG) di KLHK mengacu pada Peraturan Menteri LHK Nomor P.28/MenLHK/Setjen/KUM.1/2/2016 tentang Jaringan Informasi Geospasial Lingkup KLHK, Peraturan Dirjen PKTL Nomor: P.4/PKTL/SETDIT/KUM.1/3/2020 tentang Pedoman Penyelenggaraan dan Penyebarluasan Informasi Geospasial Lingkup Kementerian Lingkungan Hidup dan Kehutanan, dan Kep. Dirjen PKTL SK.28/2020 untuk aspek kelembagaan dan sumber daya manusia. Dalam Perdirjen PKTL tersebut dijelaskan mengenai prinsip pengelolaan dan penyebarluasan informasi geospasial yaitu: terintegrasi, 
akurat, aman, transparan, sederhana, tidak eksklusif, wajar, tidak diskriminatif, pengakuan dan penyebutan, dan ketepatan.

Ketersediaan data merupakan hal utama yang saat ini menjadi isu yang terus menerus diperbaiki. Saat ini terdapat dua database yang dapat diakses dalam penyelenggaraan informasi geospasial di KLHK yaitu geodatabase IPSDH dan geportal KLHK atau webGIS KLHK. Geoportal KLHK dapat diakses oleh publik secara terbuka melalui tautan geoportal.menlhk.go.id atau webgis.menlhk.go.id. Geoportal juga menyediakan halaman dalam bentuk mapservice yang memungkinkan pengunduhan format data shapefile bagi pengguna yang memiliki kemampuan untuk pengolahan data tersebut. Geoportal KLHK atau webGIS kehutanan juga dapat diakses secara terbuka dan melayani pengunduhan data dalam bentuk .jpeg ataupun .pdf. Tabel 2 memperlihatkan tema-tema data spasial yang dapat diakses secara terbuka melalui geoportal dan webGIS KLHK.

Tabel 2. Daftar data spasial yang bersifat terbuka pada geoportal KLHK

\begin{tabular}{|c|c|c|c|}
\hline No. & Tema Data Spasial & No. & Tema Data Spasial \\
\hline 1. & Kawasan Hutan & 16. & $\begin{array}{l}\text { Izin Usaha Pemanfaatan Hasil Hutan Kayu } \\
\text { (IUPHHK) - Hutan Tanaman Rakyat }\end{array}$ \\
\hline 2. & $\begin{array}{l}\text { Pelepasan Kawasan Hutan Untuk Budidaya } \\
\text { Pertanian dan Non-Kehutanan Lainnya }\end{array}$ & 17. & $\begin{array}{lrl}\text { Izin Usaha } & \text { Pemanfaatan } & \text { Hutan } \\
\text { Kemasyarakatan } & & \end{array}$ \\
\hline 3. & $\begin{array}{l}\text { Pelepasan Kawasan Hutan Untuk } \\
\text { Transmigrasi }\end{array}$ & 18. & Hak Pengelolaan Hutan Desa \\
\hline 4. & Tanah Objek Reforma Agraria & 19. & Peta Indikatif Area Perhutanan Sosial (PIAPS) \\
\hline 5. & Penutupan Lahan & 20. & Lahan Kritis \\
\hline 6. & Deforestasi & 21. & Daerah Aliran Sungai (DAS) \\
\hline 7. & Reforestasi & 22. & Mangrove \\
\hline 8. & $\begin{array}{l}\text { Peta Indikatif Penundaan Pemberian Izin Baru } \\
\text { (PIPPIB) }\end{array}$ & 23. & Sebaran hotspot \\
\hline 9. & Izin Pinjam Pakai Kawasan Hutan (IPPKH) & 24. & Fungsi Ekologi Gambut \\
\hline 10. & $\begin{array}{l}\text { Kawasan Hutan Dengan Tujuan Khusus } \\
\text { (KHDTK) }\end{array}$ & 25. & Kesatuan Hidrologis Gambut \\
\hline 11. & Ekoregion Darat dan Laut & 26. & Blok Kawasan Konservasi \\
\hline 12. & Arahan Pemanfaatan Hutan Produksi & 27. & Hutan Adat \\
\hline 13. & $\begin{array}{l}\text { Izin Usaha Pemanfaatan Hasil Hutan Kayu } \\
\text { (IUPHHK) - Hutan Alam }\end{array}$ & 28. & Wilayah Penilaian Kinerja REDD \\
\hline 14. & $\begin{array}{l}\text { Izin Usaha Pemanfaatan Hasil Hutan Kayu } \\
\text { (IUPHHK) - Hutan Tanaman Industri }\end{array}$ & 29. & Kebakaran Hutan dan Lahan \\
\hline 15. & $\begin{array}{l}\text { Izin Usaha Pemanfaatan Hasil Hutan Kayu } \\
\text { (IUPHHK) - Restorasi Ekosistem }\end{array}$ & 30. & Wilayah KPH \\
\hline
\end{tabular}

Sumber: geoportal.menlhk.go.id 
Adapun untuk geodatabase IPSDH bersifat khusus untuk lingkup internal KLHK. Walidata yang melaksanakan pengumpulan, pengolahan, penyimpanan, dan pemutakhiran informasi geospasial memiliki akses terhadap geodatabase IPSDH baik untuk melihat dan mengubah informasi geospasial yang menjadi tanggung jawabnya, dan melihat dan mengunduh informasi geospasial lainnya yang ada di geodatabase. Selain itu, Balai Pemantapan Kawasan Hutan (BPKH) juga memiliki akses terhadap geodatabase IPSDH sebagai sub-unit kliring data spasial di lingkup KLHK. Pemutakhiran data yang ada di geodatabase akan diinformasikan ke BPKH secara manual. Walaupun demikian, pihak eksternal juga dapat mengajukan surat permohonan kepada Direktur IPSDH atau Kepala BPKH dengan menyampaikan infromasi mengenai tujuan penggunaan, jenis informasi geospasial yang dibutuhkan, lokasi/cakupan wilayah, dan proposal penelitian jika berasal dari perguruan tinggi. Untuk proyek kerja sama pemerintah dengan konsultan surat permohonan harus dilampiri dengan perjanjian kerja sama dan pakta integritas. Perjanjian harus memuat tentang jaminan keamanan data dan larangan penggunaan data untuk kepentingan lain dan penyebarluasan kepada pihak-pihak di luar proyek kerja sama.

Dalam penyelenggaraan informasi geospasial ke depan, Direktorat IPSDH sudah menyusun strategi dan peta jalan penyelenggaraan informasi geospasial sampai dengan tahun 2024. Dengan prinsip "data dan informasi geospasial untuk mendukung proses pengambilan keputusan”, strategi pengelolaan informasi geospasial KLHK di antaranya:

- Membentuk kelembagaan pengelola Jaringan Informasi Geospasial (ini sudah diakomodasi dala Keputusan Dirjen PKTL)

- Menetapkan kebijakan dan regulasi di lingkup KLHK

- Penguatan walidata agar dapat menjalankan tugas dan tanggung jawabnya secara optimal

- Peningkatan kualitas data spasial dan infrastrukur jaringan

- Pemutakhiran data dari walidata dengan berlandaskan aturan yang terbaru

- Protokol data handling dan data sharing

- Pengelompokan data tematik dan standardisasi untuk memudahkan pengelolaan data

Adapun peta jalan untuk penyelenggaraan jaringan informasi geospasial (JIG) KLHK disajikan pada Gambar 8. Tahun 2020 merupakan tahun awal dimana perlu dilakukan penataan regulasi, penguatan kelembagaan. Peningkatan kualitas Informasi Geospasial Tematik dan peningkatan infrastruktur jaringan terus dilakukan dari tahun 2020-2021. Sementara itu, tahun 2021 dimulai adanya peningkatan kapasitas SDM sampai dengan 2023 sembari terus dilakukan peningkatan infrastruktur jaringan. Tahun 2024 direncanakan untuk menjadi tahun implementasi JIG dan pelaksanaan pemantauan dan evaluasi yang mengiringinya. 


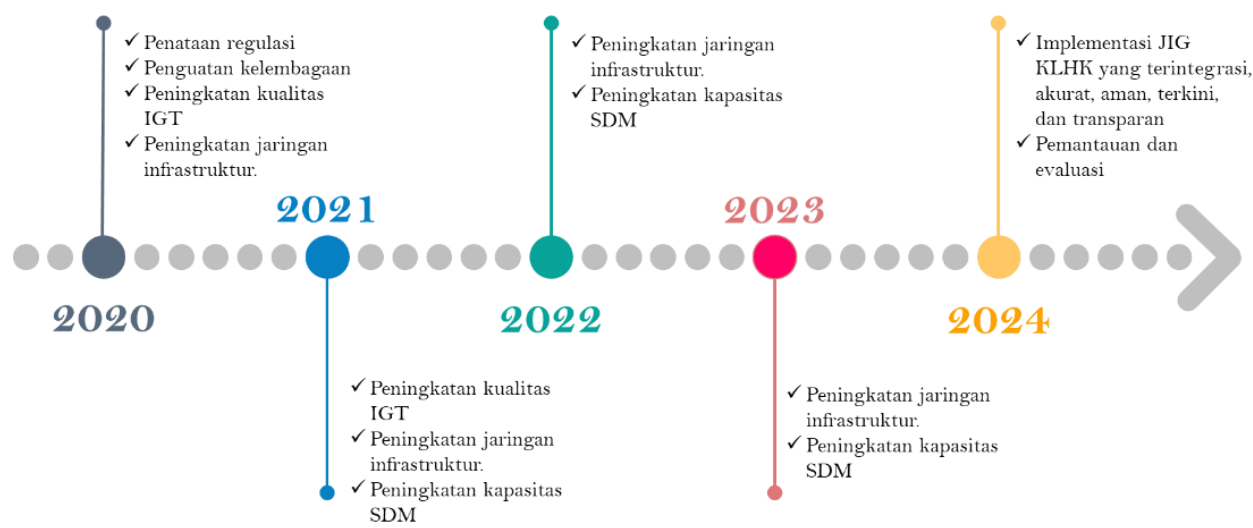

Gambar 8. Peta jalan penyelenggaraan informasi geospasial di KLHK

Penyelenggaraan informasi geospasial seperti yang sudah dijelaskan di atas secara umum sudah memulai adanya integrasi antar unit kerja dan sinkronisasi data dalam lingkup KLHK termasuk sampai unit pelaksana teknis di daerah, dalam hal ini BPKH. Namun, integrasi dan sinkronisasi data ke pemerintah daerah yang membidangi urusan kehutanan belum ditemukan, walaupun pemerintah daerah dapat mengajukan surat permohonan kepada Direktur IPSDH untuk mendapatkan data spasial. Dengan adanya UU Nomor 23 Tahun 2014 tentang Pemerintah Daerah kewenangan pengelolaan hutan tingkat tapak berada di pemerintah provinsi untuk kawasan hutan lindung dan produksi. Pengelolaan hutan tingkat tapak memerlukan data yang baik sebagai ujung tombak pengelolaan hutan. Menurut Arnold et al. (2014), kebutuhan data pada tingkat pusat, daerah, dan tapak memiliki nilai kepentingan yang sama. Pada tingkat daerah dan tapak bahkan diperlukan tingkat presisi yang lebih tinggi dan varibel yang lebih detil karena terdapat variabel yang bersifat lokal. Keamanan data juga menjadi hal yang perlu dijamin dalam berbagi pakai data. Hal ini dapat dilakukan melalui penandatanganan pakta integritas ataupun cara-cara yang bersifat lebih teknis dengan melihat timestamps pada metadata dan menggunakan watermark (Abubahia \& Cocea, 2017)

\subsection{Kendala Penerapan TIK di Bidang Kehutanan}

Adapun kendala utama dalam penerapan TIK di bidang kehutanan yang ditemui berdasarkan hasil kuesioner adalah ketersediaan infrastruktur. Infrastruktur TIK terdiri dari perangkat keras dan perangkat lunak pada masing-masing institusi maupun pembangunan TIK pada suatu wilayah. Nilai IP-TIK (Indeks Pembangunan TIK) Indonesia tahun 2019 tergolong sedang (5,32 dari 10) berdasarkan perhitungan Badan Pusat Statistik pada tahun 2020. Sementara itu, mayoritas provinsi di luar Jawa dimana mayoritas hutan berada, masih tergolong kategori rendah $(<5)$. Tabel 3 memperlihatkan bahwa hanya DKI Jakarta yang memiliki nilai IP-TIK tinggi $(7,26-10,00)$ sementera provinsi lainnya mayoritas berada pada tingkat sedang $(5,01-7,25)$ dan rendah (2,51-5,00). Beberapa provinsi membutuhkan perhatian dalam hal infrastruktur TIK, di antaranya: Provinsi Nusa Tenggara Barat, Nusa Tenggara Timur, Sulawesi Barat, Maluku Utara, dan Papua. Kondisi ini tentunya mempengaruhi kegiatan pengelolaan hutan berbasis TIK di wilayah - wilayah tersebut yang memiliki kawasan hutan dengan jumlah cukup besar. Selain infrastruktur, sumber daya manusia dan anggaran juga menjadi kendala dalam penerapan TIK. Sumber daya manusia 
dan anggaran merupakan hal yang tidak dapat dipisahkan karena kualitas sumber daya manusia bergantung pada anggaran yang dialokasikan. Sementara itu, urusah kehutanan sebagaimana diatur dalam UU No 23 Tahun 2014 tentang Pemerintahan Daerah merupakan urusan pilihan yang seringkali dikonotasikan bukan merupakan urusan yang prioritas. Maka dari itu, diperlukan komitmen yang konsisten dari pemerintah daerah untuk mengelola hutan dengan lebih baik.

Tabel 3. Nilai IP-TIK dan persentase kawasan hutan per provinsi

\begin{tabular}{|c|c|c|}
\hline Provinsi & Nilai IP-TIK & Persentase kawasan hutan \\
\hline DKI Jakarta & 7,31 & 0,72 \\
\hline D.I Yogyakarta & 6,91 & 5,37 \\
\hline Bali & 6,23 & 22,02 \\
\hline Kepulauan Riau & 6,14 & 46,56 \\
\hline Kalimantan Timur dan Kalimantan Utara & $6,14 \& 5,76$ & 67,63 \\
\hline Banten & 5,8 & 20,88 \\
\hline Jawa Barat & 5,63 & 23,08 \\
\hline Sulawesi Utara & 5,33 & 50,17 \\
\hline Riau & 5,25 & 62,13 \\
\hline Kalimantan Selatan & 5,23 & 45,94 \\
\hline Jawa Timur & 5,2 & 28,4 \\
\hline Jawa Tengah & 5,17 & 19,73 \\
\hline Sumatera Barat & 5,12 & 55,77 \\
\hline Sulawesi Selatan & 5,1 & 43,44 \\
\hline Papua Barat & 5,07 & 88,14 \\
\hline Sumatera Utara & 4,94 & 41,87 \\
\hline Kalimantan Tengah & 4,92 & 82,68 \\
\hline Jambi & 4,91 & 41,92 \\
\hline Kepulauan Bangka Belitung & 4,89 & 39,19 \\
\hline Bengkulu & 4,88 & 46,42 \\
\hline Sulawesi Tenggara & 4,83 & 61,11 \\
\hline Sumatera Selatan & 4,81 & 37,2 \\
\hline Gorontalo & 4,75 & 73,26 \\
\hline Maluku & 4,68 & 83,35 \\
\hline D.I Aceh & 4,66 & 61,26 \\
\hline Sulawesi Tengah & 4,51 & 63,62 \\
\hline
\end{tabular}




\begin{tabular}{|l|r|r|}
\hline \multicolumn{1}{|c|}{ Provinsi } & Nilai IP-TIK & \multicolumn{1}{c|}{ Persentase kawasan hutan } \\
\hline Lampung & 4,5 & 29,02 \\
\hline Kalimantan Barat & 4,48 & 55,66 \\
\hline NTB & 4,38 & 55,77 \\
\hline Maluku Utara & 4,24 & 78,84 \\
\hline Sulawesi Barat & 4,14 & 65,07 \\
\hline NTT & 3,77 & 30,5 \\
\hline Papua & 3,3 & 92,05 \\
\hline
\end{tabular}

Sumber: (KLHK, 2020) dan (BPS, 2020)

\subsection{Usulan Terobosan Dalam Penerapan TIK di Bidang Kehutanan}

Responden yang berpartisipasi dalam kuesioner juga memberi masukan terkait dengan penerapan TIK di bidang kehutanan. Berikut merupakan rangkuman dari saran dan terobosan yang dituliskan oleh responden pada kuesioner dengan analisis kata-kata yang dilakukan pada kajian ini. Agar menjadi perhatian bahwa saran yang disebutkan berikut tidak menggambarkan secara umum saran dari semua pemangku kepentingan kehutanan di seluruh Indonesia, namun hanya masukan dari beberapa perwakilan yang berpartisipasi dalam kuesioner ini.

- Pengelolaan data yang lebih baik tidak hanya berfokus pada aspek ketersediaan data, namun juga mulai memasukan aspek lainnya seperti digitalisasi, integrasi, pemutakhiran, sinkronisasi, transparansi, standardisasi, dan validasi.

- Peningkatan kualitas dan kuantitas SDM dalam mendukung penerapan TIK pada bidang kehutanan.

- Penguatan pengelolaan hutan tingkat tapak.

- Pemanfaatan teknologi terkini yang mudah dan murah.

- Pemenuhan kebutuhan infrastruktur jaringan internet terutama pada level tapak.

\subsection{Kebutuhan Dalam Rangka Menuju Kehutanan 4.0}

Dalam menuju Kehutanan 4.0, beberapa aspek teridentifikasi sebagai kebutuhan di bidang kehutanan yang harus dipenuhi di antaranya: regulasi dan kebijakan, sumber daya manusia, kelembagaan, standardisasi, infrastruktur pendukung, dan akumulasi inovasi teknologi. Anggaran tidak termasuk dalam daftar tersebut karena anggaran dalam hal ini berperan sebagai syarat mutlak bagi keenam kebutuhan tersebut untuk dipenuhi. Anggaran tidak bersifat langsung namun berdampak besar terhadap ketersediaan pemenuhan tersebut. Regulasi merupakan kebutuhan yang menjadi prioritas utama dalam menuju Kehutanan 4.O. Regulasi berperan penting dalam mengatur hubungan antara berbagai pemangku kepentingan yang terlibat dalam pengelolaan hutan berbasis TIK. Regulasi juga berperan sebagai instrumen fundamental yang harus diacu sebelum berbagai aspek lainnya dipenuhi. 


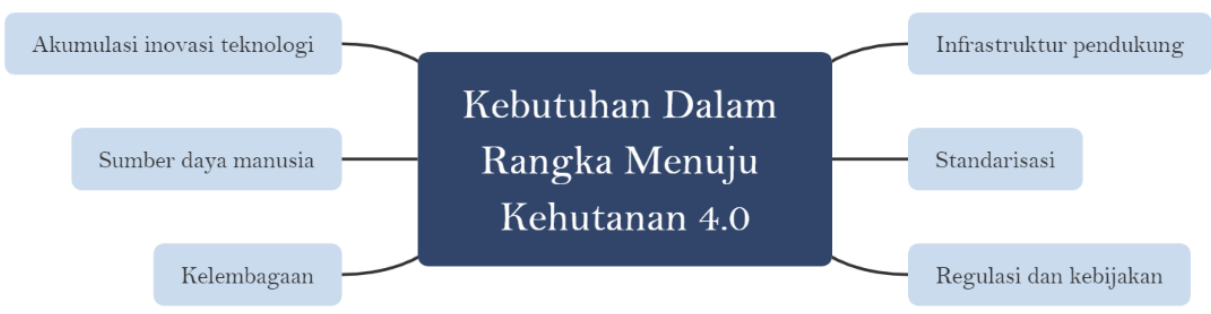

Gambar 9. Kebutuhan bidang kehutanan menuju Kehutaan 4.0

Kebutuhan berikutnya yang menjadi prioritas adalah sumber daya manusia. Pengelolaan hutan berbasis TIK sangat bergantung pada kapasitas sumber daya manusia yang mengoperasikan teknologi, baik teknologi 3.0 maupun 4.0. Pengembangan sumber daya manusia perlu menjadi perhatian utama sebagai bentuk tindak lanjut dari regulasi yang sudah dibuat. Penggunaan teknologi dalam pengelolaan hutan sangat bergantung pada kapasitas sumber daya manusia yang menggunakannya. Pada level tapak, terutama untuk institusi KPH kondisi sumber daya manusia masih cenderung kurang memadai untuk bisa melakukan pengelolaan hutan berbasis TIK. Selain itu, usaha untuk mencapai Kehutanan 4.0 bukan hanya menjadi tugas dari pemerintah. Proses untuk bisa mencapai Kehutanan 4.0 juga perlu ada kerja sama dengan masyarakat dan mitra pembangunan yang memiliki integritas dan komitmen yang kuat. Pihak nonpemerintah dapat menyediakan bantuan dalam bentuk donor, fasilitasi, ataupun teknologi yang dapat menjadi solusi atas keterbatasan faktor-faktor pendukung yang masih menjadi kendala sampai saat ini. Dukungan ini kemudian dapat merespon akumulasi teknologi yang ada di bidang kehutanan itu sendiri.

Terakhir, akumulasi teknologi dan infrastruktur perlu terus ditingkatkan bersamaan dengan pemenuhan kebutuhan utama menuju Kehutanan 4.O. Akumulasi teknologi akan terus berjalan bahkan tanpa intervensi dari kebijakan karena didorong oleh kebutuhan akan data yang berkualitas untuk mendukung pengambilan keputusan. Akumulasi ini bersifat baik jika kebutuhan di bidang kehutanan untuk menerapkan teknologi 4.0 dapat dipenuhi dan diterapkan untuk perlahan bergerak menuju Kehutanan 4.0.

\section{Kesimpulan dan Tindak Lanjut}

Berdasarkan kajian yang dilakukan tergambarkan bahwa kondisi penerapan TIK dalam bidang kehutanan saat ini masih memerlukan peningkatan pada beberapa aspek. KPH merupakan institusi yang memerlukan perhatian serius karena cenderung lebih tertinggal dibandingkan dengan insititusi kehutanan lainnya. Sementara itu, terkait dengan kebutuhan sektor kehutanan dalam menuju Kehutanan 4.0, kerangka regulasi dan sumber daya manusia merupakan hal yang harus diutamakan. Berkaitan dengan hal-hal tersebut, tindak lanjut perlu dilakukan untuk meningkatkan kualitas penyelenggaraan kebijakan kehutanan yang berbasis bukti. Berikut merupakan beberapa tindak lanjut yang perlu untuk dilakukan berdasarkan temuan dari studi:

a. Saat ini kondisi faktor pendukung penerapan TIK di bidang kehutanan untuk menuju Kehutanan 4.0 dinilai masih belum optimal terutama di institusi KPH. Diperlukan adanya fokus dari Pemerintah Pusat untuk meningkatkan pengelolaan hutan di tingkat 
tapak. Koordinasi antara Pemerintah Pusat dan Daerah harus diperkuat mengingat adanya perbedaan kewenangan pengelolaan hutan lindung dan produksi antara Pusat dan Daerah. Diperlukan adanya ruang untuk diskusi mengenai pedoman dan standar yang seringkali bersifat top-down dari Pemerintah Pusat agar dapat mengakomodasi konteks lokal. Komitmen dari Pemerintah Daerah untuk memprioritaskan kegiatan kehutanan juga perlu untuk dipertegas sehingga pengelolaan hutan di tingkat tapak (KPH) tidak tertinggal. Selain itu kerja sama antara pengelola hutan dan non-pengelola hutan perlu untuk ditingkatkan mengingat pihak non-pengelola hutan memiliki sumber daya manusia, teknologi, maupun pendanaan yang baik untuk diterapkan di tingkat tapak.

b. Penyelenggaraan Informasi Geospasial bidang kehutanan di level pusat yang ada saat ini dinilai perlu meningkatkan aksesibilitas data sampai dengan pengelolaan hutan tingkat tapak (KPH) agar tercapainya sinkronisasi data. Di sisi lain, Pemerintah Daerah dan KPH juga perlu diberikan ruang untuk melakukan inventarisasi dan pemetaan kondisi hutan di wilayahnya secara mandiri. Harapannya adalah ketersediaan data bersumber langsung dari daerah dengan adanya pengawasan dari Pusat. Selain itu, ketersediaan data saja dinilai tidak cukup dalam membantu menyelesaikan masalah kehutanan. Pengelolaan data yang lebih baik sebaiknya mencakup aspek digitalisasi, integrasi, pemutakhiran, sinkronisasi, transparansi, standardisasi, dan validasi.

c. Transformasi bidang kehutanan menuju Kehutanan 4.0 harus dimulai dari masalah yang ada saat ini dan tidak menunggu semua faktor pendukung berada dalam keadaan siap. Penerapan TIK saat ini berasal dari kebutuhan akan solusi yang terus berkembang penggunaannya. Pendekatan gradual dapat diterapkan untuk membiasakan (familiarize) kegiatan di bidang kehutanan dengan TIK sehingga kapasitas dan kesiapan terbangun secara merata. Hal-hal besar yang fundamental juga perlu dipersiapkan dalam bentuk regulasi, standar/pedoman, dan sistem keamanan data yang terjamin. Regulasi juga diharapkan untuk mencakup penerapan teknologi 4.0 dalam bidang kehutanan. Baik proses gradual maupun fundamental tidak dapat berjalan masingmasing. Kebutuhan akan kerangka regulasi perlu untuk dipenuhi pada tahap awal yang kemudian ditindak lanjuti dengan penerapan secara bertahap untuk membiasakan penerapan TIK di bidang kehutanan melalui peningkatan kapasitas SDM dan infrastruktur agar tidak kehilangan momentum.

\section{Daftar Pustaka}

Abubahia, A., \& Cocea, M. (2017). Advancements in GIS map copyright protection schemes-A critical review. Multimedia Tools and Applications, 76(10), 12205-12231. https://doi.org/10.1007/s1 1042-016-3441-Z

Alekseev, A. N., Buraeva, E. V., Kletskova, E. V., \& Rykhtikova, N. A. (2019). Stages of Formation of Industry 4.0 and the Key Indicators of Its Development. In E. G. Popkova, Y. V. Ragulina, \& A. V. Bogoviz (Eds.), Industry 4.O: Industrial Revolution of the 21st Century (pp. 93-100). Springer International Publishing. https://doi.org/10.1007/978-3-319-94310-7_9

Arnold, F.-E., van der Werf, N., \& Rametsteiner, E. (2014). Strengthening evidence-based forest policy-making. FAO. 
Austin, K. G., Schwantes, A., Gu, Y., \& Kasibhatla, P. S. (2019). What causes deforestation in Indonesia? Environmental Research Letters, 14(2), 024007. https://doi.org/10.1088/1748-9326/aaf6db

Badan Pusat Statistik. (2020). Indeks Pembangunan Teknologi Informasi dan Komunikasi 2019. Badan Pusat Statistik.

Budiningsih, K., Ekawati, S., Gamin, G., Sylviani, S., Suryandari, E. Y., \& Salaka, F. (2015). Tipologi Dan Strategi Pengembangan Kesatuan Pengelolaan Hutan di Indonesia. Jurnal Analisis Kebijakan Kehutanan, 12(3), 283-298. https://doi.org/10.20886/jakk.2015.12.3.283-298

Castrén, T., \& Pillai, M. (2011). Forest governance 2.0: A primer on ICTs and governance. Program on Forests (PROFOR).

Choudhry, H., \& O’Kelly, G. (2018, Juni). The precision forestry revolution. McKinsey. https://www.mckinsey.com/industries/paper-forest-products-and-packaging/ourinsights/precision-forestry-a-revolution-in-the-woods

Curtis, P. G., Slay, C. M., Harris, N. L., Tyukavina, A., \& Hansen, M. C. (2018). Classifying drivers of global forest loss. Science, 361(6407), 1108-1111. https://doi.org/10.1126/science.aau3445

Kementerian Lingkungan Hidup dan Kehutanan. (2020). Statistik Lingkungan Hidup dan Kehutanan Tahun 2019.

Lu, Y. (2017). Industry 4.0: A survey on technologies, applications and open research issues. Journal of Industrial Information Integration, 6, 1-10. https://doi.org/10.1016/j.jii.2017.04.005

Reynolds, K., Borges, J., Vacik, H., \& Lexer, M. (2005). ICT in Forest Management and Conservation (pp. 150-171).

Sinabutar, P., Nugroho, B., Kartodihardjo, H., \& Darusman, D. (2015). Kepastian Hukum dan Pengakuan Para Pihak Hasil Pengukuhan Kawasan Hutan Negara di Provinsi Riau. Jurnal Analisis Kebijakan Kehutanan, 12(1), 27-40. https://doi.org/10.20886/jakk.2015.12.1.27-40

Ziemba, E., Papaj, T., Żelazny, R., \& Jadamus-Hacura, M. (2016). Factors Influencing The Success Of E-Government. Journal of Computer Information Systems, 56(2), 156-167. https://doi.org/10.1080/08874417.2016.1117378 